
\title{
R Reserach S Suare \\ Effects of Nitrogen Fertilizer and Faba Bean Density in Rotation on Maize Production and Soil Parameters Under No-Till System
}

\section{Samaneh Ghorbi}

University of Mohaghegh Ardabili

Ali Ebadi ( $\nabla$ ali.ebadi.khazineh@gmail.com )

University of Mohaghegh Ardabili

Saeid Khomari

University of Mohaghegh Ardabili

Masoud Hashemi

University of Massachusetts

\section{Research Article}

Keywords: nitrogen, fertilizer, Faba bean, Agriculture

Posted Date: October 21st, 2021

DOI: https://doi.org/10.21203/rs.3.rs-953580/v1

License: (9) This work is licensed under a Creative Commons Attribution 4.0 International License. Read Full License 


\section{Abstract}

Achieving food security and environmental sustainability is a huge global challenge. Thus, the use of conservation Agriculture systems seems necessary. We investigated the effects of nitrogen fertilizer and various densities of faba bean ( vicia faba L.) on forage corn (Zea mays L.) production in the no-till system with faba bean residues preservation on the soil surface. The effect of faba bean densities on yield and its yield components, as well as soil chemical and physical properties, was studied Simultaneously. The results showed that various densities of faba bean and nitrogen fertilizer increased dry biomass production of forage corn by improving $\mathrm{N}$ content in plants, which was achieved by the density of 40 plants per $\mathrm{m}^{2}$ of faba bean + application of $200 \mathrm{~kg} \mathrm{~N} \mathrm{ha}^{-1}$ of maize. Moreover, $\mathrm{N}$ content, crude protein, and fresh biomass production in forage corn were significantly increased by faba bean density and nitrogen fertilizer. Faba bean density also affected on yield and yield component of faba bean, and the highest nitrogen released value of faba bean root residues was obtained from the density of 40 plants per $\mathrm{m}^{2}$ and application of $200 \mathrm{~kg} \mathrm{~N} \mathrm{ha}^{-1}$. Therefore, the density of 40 plants per $\mathrm{m}^{2}$ of faba bean in a rotation system with mays and application of $200 \mathrm{~kg} \mathrm{~N} \mathrm{ha}^{-1}$ be recommended as a fertilizer control method where it reduces the application of $\mathbf{N}$ fertilizer and increases the sustainability of production in agricultural systems.

\section{Introduction}

The most major challenge for global food production is to increase crop productivity with a less negative impact on the environment[1]. In the other words, the expansion of intensive crop production systems and the excessive application of chemical fertilizers and pesticides cause many problems, including environmental contaminations and a reduction in biodiversity. These systems of cultivation and their negative impact on agro-ecosystems cause increasing concern. Therefore, we are looking for alternative agricultural systems with improved efficiency and sustainability as well as high productivity[2]. Conservation Agriculture (CA) is a sustainable crop production system that includes a range of farming practices adapted to crop requirements and local conditions of the region, protecting the soil and environment from degradation and improving crop production. The no-till system is one of the primary and important methods in $\mathrm{CA}[3]$. It has been known as an appropriate approach that increases agricultural sustainability and decreases greenhouse gas emissions and global soil quality and pollution concerns[4][5]. Mulching is also one of the other methods of Conservation Agriculture which covers the soil surface with varied covering materials and decreases moisture losses and increases crops yield[6]. No-till system and mulching are some of the recommended options to reduce soil erosion and increase maize yield in Nepal[7].

Nitrogen $(\mathrm{N})$ is an essential element and plays a critical role in processes such as growth, leaf areaexpansion, photosynthesis, yield, protein, and dry matter production in plants. Insufficient value of $\mathrm{N}$ in the plant can hinder the growth and development Which ultimately decreases crops yield. In contrast, excessive $\mathrm{N}$ value in the plant (due to high application of $\mathrm{N}$ chemical fertilizer) can decrease yield via decreasing sugar content and increasing diseases and pests. Excessive application of $\mathrm{N}$ fertilizer is not 
economically cost-effective and can also pollute groundwater. Nitrogen can also be provided by organic fertilizers, legumes (e.g., cover crops), and mineralization of soil organic nitrogen.

Plant density plays an important role in capacity exploiting the environment with varying competitive stresses. High plant density can cause high lodging, low light penetration in the crop canopy, and reduced photosynthetic efficiency thereby can significantly reduce crop yield; in contrast, low plant density can result in low yield, more weed density, and poor radiation-use efficiency[8]. The optimal planting density varies depending on the variety and location, as various locations have different soil fertility[9].

By selecting Conservation Agriculture and using management practices such as no-till system and put plant residues on the soil surface, soil fertility and production stability can be increased in such systems[10][11][12][13]. The main hypothesis is that faba bean-maize rotation with residue conservation on the surface and $\mathrm{N}$ fertilizer application increases yield and improves soil fertility compared with maize monocrop. Therefore, The aims of this study were to (1) find the optimum faba bean density and its effect on economic yield as well as biological nitrogen fixation, (2) evaluate the effects of varied faba bean densities on soil physical and chemical properties, (3) and finally, determine the effects of various faba bean densities and $\mathrm{N}$ application on yield and quality of forage corn.

\section{Results}

\section{Response of yield and yield components to various densities of faba bean.}

General overview of the result showed that various plant densities influenced on yield and yield component of faba bean, in both years (Table 3). The number of pods and seeds per plant increased when plant density decreases from 80 plants to 20 plants per $\mathrm{m}^{2}$ (Table 3). Yield significantly decreased in response to decreased plant density (Table 3). At finally, dry matter production was higher in high plant densities compared to low plant densities (Table 3). Similar results were obtained in both years.

\section{Effects of various fava bean densities and $\mathrm{N}$ application on the release value of nitrogen in the soil.}

Our results showed that density of 40 plants per $\mathrm{m}^{2}$ of fava bean and application of $200 \mathrm{~kg} \mathrm{~N} \mathrm{ha}^{-1}$ had the release value of nitrogen and root decomposition rate more than other treatments, after that, the density of 80 plants per $\mathrm{m}^{2}$ of fava bean and application of $300 \mathrm{~kg} \mathrm{~N} \mathrm{ha}^{-1}$ and density of 40 plants per $\mathrm{m}^{2}$ of fava bean and application of $100 \mathrm{~kg} \mathrm{~N} \mathrm{ha}^{-1}$ had the highest decomposition rate of the root, in both years (Figure 1, 2).

\section{Effects of various fava bean densities on soil chemical and physical properties.}

Various plant density was not influenced by changes of the organic carbon, organic matter, EC, bulk density, soil moisture stock, and total porosity of soil. However, varied plant densities significantly affected on infiltration rate and moisture content of soil. When plant density increases from 20 plants to 
80 plants per $\mathrm{m}^{2}$, infiltration rate and moisture content of soil were increased in the soil (Table 3 ). All data were nearly similar in both years.

\section{Effect $\mathrm{N}$-fertilizer application and cover crop rotation systems on $\mathrm{N}$ content, Crude Protein, dry and fresh matter production of forage corn.}

The interaction effects of $\mathrm{N}$ application and fava bean residues had a significant positive effect on $\mathrm{N}$ content, Crude Protein, dry and fresh matter production of forage corn in both years (Table 4). The least increase in dry matter production was obtained from the control treatment (monoculture mays without $\mathrm{N}$ application), while the density of 40 plants per $\mathrm{m}^{2}$ of fava bean and application of $200 \mathrm{~kg} \mathrm{~N} \mathrm{ha}^{-1}$ had the highest value of dry matter production (Table 4). Also, the highest value of fresh matter production was observed in the density of 40 plants per $\mathrm{m}^{2}$ of fava bean and application of $100 \mathrm{~kg} \mathrm{~N} \mathrm{ha}^{-1}$ and monoculture mays without $\mathrm{N}$ application had the least value of fresh matter production (Table 4). Among the faba bean densities, the density of 40 plants per $\mathrm{m}^{2}$ and application of $200 \mathrm{~kg} \mathrm{~N} \mathrm{ha}^{-1}$ were caused the highest increase of $\mathrm{N}$ content in forage corn. The lowest $\mathrm{N}$ content of forage corn was obtained from the control treatment (monoculture of mays without $\mathrm{N}$ application) (Table 4). Crude protein contents increased with various densities of faba bean and application of $\mathrm{N}$ fertilizer. The highest crude protein content was obtained from the density of 40 plants per $\mathrm{m}^{2}$ of fava bean and application of $200 \mathrm{~kg} \mathrm{~N} \mathrm{ha}^{-1}$ and the lowest protein content was obtained from monoculture mays without $\mathrm{N}$ application (control treatment) (Table 4). Similar results were obtained in both years.

\section{Discussions}

Seed yield of faba bean is the product of several components include the number of pods and seeds which have an important role in yield. The high plant densities, decrease the available area to each plant. This matter has an important role in decreasing yield and yield components. In the other words, high plant densities could be increased interplant competition during the early vegetative stages. This early competition increases shading between leaves and respiration rate which leading to insufficient carbon fixation[14]. In contrast, in low plant densities, plants have more access to light, nutrients, and moisture which in turn increases the synthesis of metabolites. Tuarira and Moses[15] reported that the highest number of pods and seeds per plant was obtained in low plant density. Woldesenbet and Mekonnen[16] also expressed that the number of seeds per pod of common bean had increased with decreasing plant density. Moreover, Gezahegn[17] expressed the number of pod and seed (per plant) of faba bean was significantly reduced with increasing plant density. Dry matter was also higher in high plant densities compared to low plant densities. This may be due to the higher LAI which provided a larger surface for light interception which led to higher photosynthesis and greater biomass per unit area. Al-Rifaee[18] also reported a positive effect of increasing plant density on dry biomass production.

Crops residue is decomposed slowly in the soil and improved of soil fertility that allowed the next plants make use of them gradually and more efficiently. When plant residues are mixed into soil, the mineralization of plant residue nitrogen contributes to the soil's inorganic nitrogen. It was expected that 
the highest releasing $N$ value of root residues was obtained from the density of 80 plants per $\mathrm{m}^{2}$, but our results showed that the highest $\mathrm{N}$ value of root residues was released from the density of 40 plants per $\mathrm{m}^{2}$. It should be noted that in high plant density, these changes can be attributable to microbial activity and population. The activity of microbial communities depends on the existence of adequate value of nitrogen in the soil, and the decomposition of plant residues decreases when the $\mathrm{N}$ value is not sufficient. Also, the size of plant residues and their $\mathrm{C} / \mathrm{N}$ ratio influence the soil microbial activity, exchange of water, oxygen, and nutrients between soils and straw residues[19][20]. Our finding showed that the highest plant residues Per unit area will cause $\mathrm{N}$ deficiency both for residue decomposition and for the subsequent crops. Thereby, a major part of $\mathrm{N}$ fertilizer uses by microorganisms for decomposed root residues which might be not enough. Martens[21] showed a correlation between the rate of plant residue decomposition and their biochemical composition. Our result is in agreement with previous studies[22][23]. Studies showed that $\mathrm{N}$ application accelerates the decomposition rate of plant residues[24][25]. Makoi[26] also reported high density of cowpea was decrease symbiotic performance.

One of the key soil hydraulic properties is water infiltration and moisture content of the soil. In our study, water infiltration rate and moisture content increased with increasing plant density. Many of weeds are known to be water wasters that consume or transpire much water daily and one possible explanation is that the weeds population (such as common Amaranth and goosefoot) decreases by increasing crop density. Chavarria[27] and Verzeaux[28] expressed that higher legume biomass improved soil moisture content. It seems that weeds root distribution is more than faba bean which enables weeds to better competition as well as more efficient use of water compared with crops. At finally, many soil properties such as soil organic matter, slowly respond to management changes and treatment effects may not be measured within a short period.

The results showed that dry and fresh matter production of forage corn was strongly affected by different levels of $\mathrm{N}$ application and $\mathrm{N}$ content in the faba bean residues but its effect will gradually decrease when the $\mathrm{N}$ application level increases. Increasing nitrogen in the soil can improved $\mathrm{N}$ accumulation in the plant which caused increasing dry and fresh matter production. Also, imbalanced rates and injudicious methods of fertilizer application can lead to poor $\mathrm{N}$ efficiency, $\mathrm{N}$ losses due to leaching and other chemical and biological processes in the soil[29][30], resulting in a series of environmental hazards and economic loses. Nyagumbo[31], Uzoh[32] and Franke[33] expressed that corn-soybean rotation caused increasing corn yield compared with corn-cereal rotation. Also, recent research showed that the cornsoybean rotation can preserved crop production in high levels after years compared with monoculture corn[34]. Total $\mathrm{N}$ uptake was increased by increasing $\mathrm{N}$ fertilizer application and faba bean residues but its effect will also gradually decrease when the $\mathrm{N}$ application level increases. This point shows that interaction of faba bean residues and medium rates of $\mathrm{N}$ application could be enhanced $\mathrm{N}$ content of forage corn. A positive influence by the legume residues was recorded on the cereal yield and $\mathrm{N}$ uptake[35]. Our results showed that crude protein content was increased when $\mathrm{N}$ value increased in plants, this may be due to fact that nitrogen has an important role in the protein synthesis, thereby protein 
content increased with increasing $\mathrm{N}$ value in the plant. Islam[36] and Safdarian[37] also expressed that crude protein increased when $\mathrm{N}$ application increased.

\section{Materials And Methods}

Study site. A field experiment was conducted in two growing seasons (2018-2019) at the research farm of Agriculture and Natural Resources Faculty, University of Mohaghegh Ardabili, located in Babolan village, Ardebil, Iran. Ardebil is located between latitude $38^{\circ} 15 \mathrm{~N}$ and longitude $48^{\circ} 15 \mathrm{E}$ and $1350 \mathrm{~m}$ above sea level. The climate in the study area is semi-arid and cold (very cold winters, and mild summers) according to the Koppen classification[38]. The climatic conditions of the area during the experiment are indicated in Table 1. The soil type was loamy with 35, 42, and 23 (\%) sand, silt, and clay, respectively. In the last year, the field was fallow with the dominance of annual broadleaf weeds such as common Amaranth (Amaranthus retroflexus L.) and goosefoot (Chenopodium album). To determine the initial soil chemical properties ( $\mathrm{PH}$, soil organic matter, $\mathrm{Zn}^{2+}, \mathrm{K}^{+}, \mathrm{P}$, total $\mathrm{N}$, lime, and base saturation), soil samples were taken at depths of $0-20 \mathrm{~cm}$ soil with several replications in the field and are shown in Table 2. Soil pH was measured in a $0.01 \mathrm{~mol} \mathrm{~L}^{-1} \mathrm{CaCl} 2$ suspension[39]. The chromic acid digestion method was used to determine soil organic matter[40]. Available $\mathrm{P}$ was determined by spectrophotometer[41] and $\mathrm{Zn}^{2+}, \mathrm{K}^{+}$ were extracted with a flame atomic absorption spectrophotometry[42]. Total $\mathrm{N}$ was measured by the Kjeldahl method[43].

\section{Field establishment and treatment application}

The experimental design was a factorial based on a randomized complete block design with three replicates in each growing season. Experimental treatments have consisted of faba bean densities $(25$, 35,40 , and 80 plants per square meter) and different levels of nitrogen $(\mathrm{N})$ fertilizer in forage corn $(0,100$, 200 , and $300 \mathrm{~kg} \mathrm{ha}^{-1}$ )[44]. Al-Suhaibani[45] expressed that the optimum plant density of faba bean to obtain high productivity can range 10 to 100 plant per $\mathrm{m}^{2}$ and in order to, agronomic management of weeds, faba bean density was considered higher in this experiment[46]. The size of each plot was $3 \mathrm{~m} \times 4$ $\mathrm{m}$ which separated with a $1 \mathrm{~m}$ path between replicates and to avoid mixing effects of fertilizers, a $1 \mathrm{~m}$ path between all plots was considered. Faba bean (Vicia faba L. cv. Shadan/G-Faba-133) (LineF6/Latt338/08) was used in this experiment. This cultivar was introduced by Seed and Plant Improvement Institute of Iran in 2016[47]. 1. 5. 5. 6 code is a registry code for this cultivar in Seed and Plant Certification and Registration Institute[47]. Seeds were sown on 3th March after soaking in water and inoculated with Rhizobium leguminosarum var viciae[48]. To improve nodulation of faba bean plant, $20 \mathrm{~kg} \mathrm{ha}^{-1}$ of $\mathrm{N}$ fertilizer was added to the soil as starter fertilizer[49]. It was also the first time the faba bean was planted in the area. Weeds controlling were done manually at the emergency to vegetative stage[50]. The faba bean was harvested manually at the physiological maturity stage. After harvesting, the entire plant residues were left on the soil surface as mulch[51]. Thereafter, maize seeds were planted on faba bean residue rows, as the second planting, with the population of 80000 plants ha $^{-1}$ without plowed of soil[52][53]. Early maturing maize hybrid KSC 201 (a cross between K1263/17 × S61 inbred 
lines) was sown on 23th and 25th June 2018 and 2019, respectively. This cultivar is developed by Seed and Plant Improvement Institute of Iran in 2015[54]. 1. 4. 1. 57 code is a registry code for this cultivar in Seed and Plant Certification and Registration Institute in Iran[54]. The maize seedlings were emerged 7 days after sowing, on average, in each growing season. Due to the soil calcareous conditions and making iron $(\mathrm{Fe})$ unavailable for plant uptake and to the prevention of severe iron deficiency in the plant, iron foliar application (Fe-EDTA) was done in three stages and with ten days intervals in the plant[55][56]. N fertilizer was applied in the form of urea at the $\mathrm{V} 5$ stage of maize development by superficial broadcasting (in three stages)[57]. Due to the cool weather, forage corn was harvested at the kernel milk stage and 100 days after sowing. The germination test[58] was over $98 \%$ for both maize and we have prepared seeds by official permission with Seed and Plant Improvement Institute (SPII), Karaj, Iran. Seeds were hand-planted and irrigation was done properly and uniformly to grow successful crops for both crops. During the growing season of both plants, aphids appeared that were naturally controlled by ladybirds.

\section{Sampling and Analyses}

At the maturity stage of the faba bean, samples were taken from a quadrat of $0.5 \mathrm{~m} \times 0.5 \mathrm{~m}$ for each plot. Agronomic data were collected such as the number of pods, and seeds (per plant), yield and total dry biomass (tons ha- ${ }^{-1}$ ). The seeds and pods were removed from the plants in each plot and were counted. Seed yield (per hectare) was determined by harvesting seeds of plants from per plot and dried in an oven at $65^{\circ} \mathrm{C}$ for $48 \mathrm{~h}$ and weighted by digital scale $(0.01 \mathrm{~g})$ [59]. For total dry biomass, all parts of the plant at maturity from the above-ground were harvested and dried oven $65^{\circ} \mathrm{C}$ for $48 \mathrm{~h}$ and weighted by digital scale (0.01g)[59]. Finally, all data was converted to the hectare.

To calculate the amount of Nitrogen mineralization of faba bean residues was used mesh bag technique[60]. Mesh bags of polyamide nylon were made with a size of $20 \times 10 \mathrm{~cm}$. Mesh bags (each sample was contained 100 gr of Faba bean root) were buried in the $20 \mathrm{~cm}$ deep of soil and were out of the soil after the second week and weekly.

Soil samples were collected of $0-15 \mathrm{~cm}$ soil depth[61] and from three random spots in each plot before harvesting of faba bean. The soil composite sample was dried under shade and passed through a $2 \mathrm{~mm}$ sieve for soil physical and chemical analyses[62] (water infiltration rate, organic carbon, organic matter, EC, bulk density, soil moisture content, soil moisture stock, and total porosity). The soil infiltration rate was determined by a double ring infiltrometer method, based on measuring the height of water infiltrated into the soil (three replicate per experimental unit between the two central plants)[63]. The soil organic carbon was obtained by Walkely and Black procedure[64], Organic matter (OM) was computed from multiplying organic carbon by 1.724 ("Van Berminelen factor")[64]. Soil electrical conductivity was measured in a 1:25 soil/water solution using EC meters (model: Mi 180 Bench Meter)[65]. Bulk density was determined by the core method[66]. The total porosity (TP\%) was calculated by TP $=[1-(\mathrm{BD} / 2.65)] \times$ 100[63]. Soil moisture content was determined by the gravimetric method and with the following formula (the soil sample was weighted, then dried in the oven $105^{\circ} \mathrm{C}$ for $72 \mathrm{~h}$ and weighed again)[67]; 
Soil moisture content $=\frac{\text { wet soil weight }(\mathrm{g})-\text { dry soil weight }(\mathrm{g})}{\text { dry soil weight }(\mathrm{g})} \times 100$

Soil moisture stock was calculated by the following calculation[68]:

Soil moisture stock $=\frac{\text { Soil moisture content }(\%)}{100} \times$ soil bulk density $\times$ Depth $(\mathrm{cm})$

Three plants of corn were selected randomly and hand-cut above the soil surface in each plot thereafter were weighed to determine fresh forage yield. All above parts of the plant were dried in an oven at $70^{\circ} \mathrm{C}$ for $72 \mathrm{~h}$ and the weighted and dry matter production of these samples was calculated (data converted to hectare)[69]. The plant samples were ground with a mill and passed through a $2 \mathrm{~mm}$ sieve. Sieved samples were packed in small paper bags and sent to Central Laboratory of Kharazmi University (Tehran, Iran) for total nitrogen analysis (by Kjeldahl method)[42] and $\mathrm{N}$ accumulation value ( $\mathrm{kg} \mathrm{ha}^{-1}$ ) was estimated with the following formula[70]:

$\mathrm{N}$ accumulation in plant $=\frac{\left(\text { Dry matter weight } \mathrm{kg} \mathrm{ha}^{-1} \times \% \mathrm{~N} \text { in plants }\right)}{100}$

\section{Statistical analysis}

Data gotten from this research were analyzed for differences in variance (ANOVA) using the software of SAS (version 9.4) to determine the main plot and interactions treatment effects. Significant differences between the treatment means were tested with Least Significant Difference (LSD) value at $5 \%$ level of probability.

\section{Declarations}

\section{Acknowledgements}

We thank Dr. mohammadreza Shiri and Seed and Plant Improvement Institute for their help in seeds preparation.

\section{Author contributions}

The research plan and experiments were conceived and designed by S.Gh., A. E., and M. H. S. Gh. wrote the main manuscript text and performed data analysis, A.E. provided a lots of writing skills and saved a few difficulty problems in writing manuscript, S.Kh. provided academic helps. All authors reviewed the manuscript.

\section{Competing interests}

The authors declare no competing interests. 


\section{References}

1. Abdalla, M. et al. A critical review of the impacts of cover crops on nitrogen leaching, net greenhouse gas balance and crop productivity. Glob. Chang. Biol, 25, 2530-2543 (2019).

2. Javanmard, A., Amani Machiani, M., Lithourgidis, A., Morshedloo, M. R. \& Ostadi, A. Intercropping of maize with legumes: A cleaner strategy for improving the quantity and quality of forage. Clean. Eng. Technol, 1, 100003 (2020).

3. Palm, C., Blanco-Canqui, H., DeClerck, F., Gatere, L. \& Grace, P. Conservation agriculture and ecosystem services: An overview. Agric. Ecosyst. Environ, 187, 87-105 (2014).

4. Dendooven, L. et al. Greenhouse gas emissions under conservation agriculture compared to traditional cultivation of maize in the central highlands of Mexico. Sci. Total Environ, 431, 237-244 (2012).

5. Lal, R. Sequestering carbon and increasing productivity by conservation agriculture. J. Soil Water Conserv, 70, 55-62 (2015).

6. Kader, M. A. et al. Mulching as water-saving technique in dryland agriculture: review article. Bull. Natl. Res. Cent, 43, 147-153 (2019).

7. Atreya, K., Sharma, S., Bajracharya, R. M. \& Rajbhandari, N. P. Developing a sustainable agro-system for central Nepal using reduced tillage and straw mulching. J. Environ. Manage, 88, 547-555 (2008).

8. Lemerle, D., Verbeek, B. \& Diffey, S. Influences of field pea (Pisum sativum) density on grain yield and competitiveness with annual ryegrass (Lolium rigidum) in south-eastern Australia. Aust J Exp Agric, 46, 1465-1472 (2006).

9. Zeyada Elhag, A. \& Mohamed Hussein, A. Effects of Sowing Date and Plant Population on Snap Bean (Phaseolus vulgaris L.) Growth and Pod Yield in Khartoum State. Univers. J. Agric, 2, 115-118 (2014).

10. Liu, K., Bandara, M., Hamel, C., Knight, J. D. \& Gan, Y. Intensifying crop rotations with pulse crops enhances system productivity and soil organic carbon in semi-arid environments. F. Crop. Res, 248, 107657 (2020).

11. Rocha, K. F. et al. Cover crops affect the partial nitrogen balance in a maize-forage cropping system. Geoderma, 360, 114000 (2020).

12. Ginakes, P., Grossman, J. M., Baker, J. M. \& Dobbratz, M. \& Sooksa-nguan, T. Soil carbon and nitrogen dynamics under zone tillage of varying intensities in a kura clover living mulch system. Soil Tillage Res, 184, 310-316 (2018).

13. Oliveira, M., Barré, P., Trindade, H. \& Virto, I. Different efficiencies of grain legumes in crop rotations to improve soil aggregation and organic carbon in the short-term in a sandy Cambisol. Soil Tillage Res, 186, 23-35 (2019).

14. Wakweya, K., Dargie, R. \& Meleta, T. Effect of Sowing Date and Seed Rate on Faba Bean (Vicia faba L.) Growth, Yield and Components of Yield at Sinana, Highland Conditions of Bale, Southeastern Ethiopia. Inter. J. Sci. Res. Agric. Sci, 3, 25-34 (2016). 
15. Tuarira, M. \& Moses, M. Effects of Plant Density and Planting Arrangement in Green Bean Seed Production. J. Glob. Innov. Agric, 2, 152-157 (2014).

16. Woldesenbet, M. \& Mekonnen, G. Effects of common bean varieties and densities intercropped with rice on the performance of associated components in Kaffa and Benchi Maji Zones, South-western Ethiopia. Glob. J. Sci. Front. Res. Biol. Sci, 17, 32-37 (2017).

17. Gezahegn, A. M. \& Tesfaye, K. Optimum inter and intra row spacing for faba bean production under Fluvisols. MAYFEB J. Agric. Sci, 4, 10-19 (2017).

18. Al-Rifaee, M., Turk, M. A. \& Al Tawaha, A. R. M. Effect of Seed Size and Plant Population Density on Yield and Yield Components of Local Faba Bean (Vicia faba L. Major). Int. J. Agri. Biol, 6, 294-299 (2004).

19. Ibrahim, M., Cao, C. G., Zhan, M., Li, C. F. \& Iqbal, J. Changes of CO 2 emission and labile organic carbon as influenced by rice straw and different water regimes. Int. J. Environ. Sci. Technol, 12, 263274 (2015).

20. Wang, X., Jiang, Y., Sui, Y. \& Sun, B. Changes of microbial communities during decomposition of wheat and maize straw: analysis by BIOLOG. Acta Pedol. Sin, 49, 1003-1011 (2012).

21. Martens, D. A. Plant residue biochemistry regulates soil carbon cycling and carbon sequestration. Soil Biol. Biochem, 32, 361-369 (2000).

22. Marschner, P., Hatam, Z. \& Cavagnaro, T. R. Soil respiration, microbial biomass and nutrient availability after the second amendment are influenced by legacy effects of prior residue addition. Soil Biol. Biochem, 88, 169-177 (2015).

23. Zheng, B. \& Marschner, P. Previous residue addition rate and $\mathrm{C} / \mathrm{N}$ ratio influence nutrient availability and respiration rate after the second residue addition. Geoderma, 285, 217-224 (2017).

24. Parton, W. J., Stewart, J. W. B. \& Cole, C. V. Dynamics of C, N, P and S in grassland soils: a model. Biogeochemistry, 5, 109-131 (1988).

25. Rosolem, C. A. et al. Enhanced Plant Rooting and Crop System Management for Improved N Use Efficiency (ed. Sparks, D. L.). 205-239(2017).

26. Makoi, J. H. J. R., Chimphango, S. B. M. \& Dakora, F. D. Effect of legume plant density and mixed culture on symbiotic N2 fixation in five cowpea (Vigna unguiculata L. Walp.) genotypes in South Africa. Symbiosis, 48, 57-67 (2009).

27. Chavarría, D. N. et al. Effect of cover crops on microbial community structure and related enzyme activities and macronutrient availability. Eur. J. Soil Biol, 76, 74-82 (2016).

28. Verzeaux, J., Hirel, B., Dubois, F., Lea, P. J. \& Tétu, T. Agricultural practices to improve nitrogen use efficiency through the use of arbuscular mycorrhizae: Basic and agronomic aspects. Plant Sci, 264, 48-56 (2017).

29. Kirda, C., Derici, M. R. \& Schepers, J. S. Yield response and N-fertiliser recovery of rainfed wheat growing in the Mediterranean region. F. Crop. Res, 71, 113-122 (2001). 
30. Richter, J. \& Roelcke, M. The N-cycle as determined by intensive agriculture-examples from central Europe and China. Nutr. Cycl. Agroecosystems, 57, 33-46 (2000).

31. Nyagumbo, I. et al. Maize yield effects of conservation agriculture based maize-legume cropping systems in contrasting agro-ecologies of Malawi and Mozambique. Nutr. Cycl. Agroecosystems, 105, 275-290 (2016).

32. Uzoh, I. M., Igwe, C. A., Okebalama, C. B. \& Babalola, O. O. Legume-maize rotation effect on maize productivity and soil fertility parameters under selected agronomic practices in a sandy loam soil. Sci. Rep, 9, 1-9 (2019).

33. Franke, A. C., van den Brand, G. J., Vanlauwe, B. \& Giller, K. E. Sustainable intensification through rotations with grain legumes in Sub-Saharan Africa: A review. Agric. Ecosyst. Environ, 261, 172-185 (2018).

34. Agyare, W. A., Clottey, V. A., Mercer-Quarshie, H. \& Kombiok, J. M. Maize yield response in a long-term rotation and intercropping systems in the Guinea Savannah zone of Northern Ghana. J. Agron, 5, 232-238 (2006).

35. Kamkar, B. The Effect of Crop Residues on Soil Nitrogen Dynamics and Wheat Yield. Adv. Plants Agric. Res, 1, 8-14 (2014).

36. Islam, M. R., Garcia, S. C. \& Horadagoda, A. Effects of irrigation and rates and timing of nitrogen fertilizer on dry matter yield, proportions of plant fractions of maize and nutritive value and in vitro gas production characteristics of whole crop maize silage. Anim. Feed Sci. Technol, 172, 125-135 (2012).

37. Safdarian, M., Razmjoo, J. \& Dehnavi, M. M. Effect of Nitrogen Sources and Rates on Yield and Quality of Silage Corn. J. Plant Nutr, 37, 611-617 (2014).

38. Pourvahidi, P. \& Ozdeniz, M. B. Bioclimatic analysis of Iranian climate for energy conservation in architecture. Sci. Res. Essays, 8, 6-16 (2013).

39. Miller, R. O. \& Kissel, D. E. Comparison of Soil pH Methods on Soils of North America. Soil Sci. Soc. Am. J, 74, 1-7 (2010).

40. Heanes, D. L. Determination of total organic-c in soils by an improved chromic acid digestion and spectrophotometric procedure. Commun. Soil Sci. Plant Anal, 15, 1191-1213 (1984).

41. Page, A. L. et al. Methods of soil analysis. eds(1982).

42. Bunzl, K., Wolf, A. \& Sansoni, B. Kinetics of ion exchange in soil organic matter V. Differential ion exchange reactions of Cu2+-, Cd2+-, Zn2+- and Ca2+-ons in humic acid. 139,475-485(1976).

43. Bremner, J. M. \& Mulvaney, C. Nitrogen-total In: Page AL, Miller R. H., Keeney D. R., editors. Methods of soil analysis. Part 2. Agron. Monogr. ASA and ASSA, Madison WI. 9, 595-624(1982).

44. Lamptey, Yeboah, S. \& Li, L. Response of Maize Forage Yield and Quality to Nitrogen Fertilization and Harvest Time in Semi-arid Northwest China. Asian J. Res Agric Fores, 1, 1-10 (2018).

45. Al-Suhaibani, N., El-Hendawy, S. \& Schmidhalter, U. Influence of varied plant density on growth, yield and economic return of drip irrigated Faba bean (Vicia faba L.). Turk J Field Crops, 18, 185-197 
(2013).

46. Gezahegn, A. M., Tesfaye, K., Sharma, J. J. \& Belel, M. D. Determination of optimum plant density for faba bean (Vicia faba L.) on vertisols at Haramaya, Eastern Ethiopia. Cogent Food Agri, 2, 1224485 (2016).

47. https://spcri.ir/page-Main/fa/0/form/pld395.

48. Siczek, A. \& Lipiec, J. Impact of Faba Bean-Seed Rhizobial Inoculation on Microbial Activity in the Rhizosphere Soil during Growing Season. Int. J. Mol. Sci, 17, 784 (2016).

49. Mohamed, S. S. E. \& Babiker, H. M. Effects of Rhizobium inoculation andurea fertilization on faba bean (Vicia faba L.) production in a semi-desert zone. Adv. Environ. Biol, 6, 824-830 (2012).

50. Kebede, M., Sharma, J. J., Tana, T. \& Nigatu, L. Effect of Plant Spacing and Weeding Frequency on Weed Infestation, Yield Components, and Yield of Common Bean (Phaseolus vulgaris L.) in Eastern Ethiopia. East Afric J Sci, 9, 1-14 (2015).

51. Blanco-Canqui \& Lal, L. Crop Residue Removal Impacts on Soil Productivity and Environmental Quality. C. Rev. Plant Sci, 28, 139-163 (2009).

52. Roldan, A. et al. No-tillage, crop residue additions, and legume cover cropping effects on soil quality characteristics under maize in Patzcuaro watershed (Mexico). Soil \& Till Res, 72, 65-73 (2003).

53. Naderi, F., Siadat, S. A. \& Rafiee, M. Effect of planting date and plant density on grain yield and yield components of two maize hybrids as second crop in Khorram Abad.Iranian Journal of Crop Sciences.12,31-41; http://agrobreedjournal.ir/article-1-188-en.html(English abstract) (2010)(in Persian).

54. Dehghanpour, Z. et al. Kousha (KSC 201) an early maturing maize hybrid suitable for different maize growing regions of Iran particularly areas with limited growing season duration and irrigation water. Agriculture Research Education \& Extension Organization. 7, 71-82; doi.org/10.22092/rafhc. 2018.109462.1063 (2018).

55. Ghazvineh, S. \& Yousefi, M. Study the Effect of Micronutrient Application on Yield and Yield Components of Maize. 12,144-147(2012).

56. Chen, Y. \& Barak, P. Iron Nutrition of Plants in Calcareous Soils. Adv. Agro, 35, 217-240 (1982).

57. Sangoi, L., Ernani, P. R. \& Da Silva, P. R. F. Maize response to nitrogen fertilization timing in two tillage systems in a soil with high organic matter content. Rev. Bras. Cienc. do Solo, 31, 507-517 (2007).

58. Anonymous. Hand Book for Seedling Evaluation 3rd. edn (International Seed Testing Association (ISTA), Zurich, Switzerland, 2003).

59. Berkenkamp, B. \& Meeres, J. Faba bean as forage in the Parklands of Alberta. Can. J. Plant Sci, 66, 167-169 (1986).

60. Jahanzad, E. et al. Nitrogen release dynamics and decomposition of buried and surface cover crop residues. Agron. J, 108, 1735-1741 (2016).

61. Rakkar, M. R., Franzen, D. W. \& Chatterjee, A. Evaluation of Soil Potassium Test to Improve Fertilizer Recommendations for Corn. Open J Soil Sci, 5, 110-122 (2015). 
62. Uzoh, I. M., Igwe, C. A., Okebalama, C. B. \& Babalola, O. O. Legume-maize rotation effecton maize productivity and soil fertility parameters under selected agronomic practices in a sandyloam soil. Sci Report, 9, 8539 (2019).

63. Hillel, D. Introduction to soil physics (Academic Press, New York, 1982).

64. Walkley, A. \& Black, I. A. An examination of Degtjareff method for determining soil organic matter and a proposed modification of the chromic acid in soil analysis. 1. Experimental. Soil Sci, 79, 459465 (1934).

65. Zhang, Y. G. et al. Sheep manure application increases soil exchangeable base cations in a semi-arid steppe of Inner Mongolia. J. Arid Land, 7, 361-369 (2015).

66. Blake, G. R., Hartge, K. H. \& Klute, A. Methods of soil analysis (ed. Klute, A.) 363-375 (Madison, 1986).

67. Jalota, S. K., Khera, R. \& Ghuman, B. S. Methods in soil physics. 153 (Narosa Publishing House, 1998).

68. Ngangom, B. et al. Double mulching improves soil properties and productivity of maize-based cropping system in eastern Indian Himalayas. Int. Soil Water Conserv. Res, 8, 308-320 (2020).

69. Perry, L. J. \& Compton, W. A. Serial measures of dry matter accumulation and forage quality of leaves, stalks and ear of three maize hybrids. Agronomy J, 69, 751-755 (1977).

70. Sharma, N. K., Singh, R. J. \& Kumar, K. Dry Matter Accumulation and Nutrient Uptake by Wheat (Triticum aestivum L.) under Poplar (Populus deltoides) Based Agroforestry System. ISRN Agron 2012, 359673 (2012).

71. Salo-väänänenPekka, P. P. \& Koivistoinen, E. Determination of protein in foods: comparison of net protein and crude protein $(\mathrm{N} \times 6.25)$ values. 57,27-31(1996).

\section{Tables}

TABLE 1 | Rainfall, maximum and minimum temperatures, relative humidity and radiation received at Ardabil, Iran, during the study period.

TABLE 2 | Soil chemical characteristics at two depths in the experimental area before planting. 
Month

Climate

characteristics

March April May June July August September October

Year (2018)

\begin{tabular}{lcccccccc} 
Monthly rain, mm & 26.5 & 9.3 & 60.3 & 28.2 & 3.9 & 0.9 & 7.3 & 9.0 \\
$\begin{array}{l}\text { Mean max. temp., } \\
\text { oc }\end{array}$ & 12.4 & 15.7 & 18.6 & 23.5 & 29.2 & 25.8 & 24.6 & 20.1 \\
$\begin{array}{l}\text { Mean min. temp., } \\
\text { ॰c }\end{array}$ & 1.5 & 2.3 & 5.9 & 10.0 & 13.7 & 14.9 & 10.5 & 8.1 \\
\hline $\begin{array}{l}\text { Radiation received, } \\
\text { M }\end{array}$ & 157.5 & 170.9 & 196.3 & 248.6 & 344.2 & 255.6 & 282.1 & 193.4
\end{tabular}

$\mathrm{MJm}^{-2}$

\begin{tabular}{|c|c|c|c|c|c|c|c|c|}
\hline Relative humidity & 73 & 66 & 71 & 71 & 60 & 69 & 68 & 76 \\
\hline \multicolumn{9}{|l|}{ Year (2019) } \\
\hline Monthly rain, mm & 25.9 & 40 & 29.5 & 13 & 0.1 & 0 & 18.8 & 53.3 \\
\hline $\begin{array}{l}\text { Mean max. temp., } \\
\text { ॰C }\end{array}$ & 9.5 & 13.4 & 19.8 & 25.7 & 25.7 & 26.7 & 22.5 & 23.0 \\
\hline $\begin{array}{l}\text { Mean min. temp., } \\
{ }^{\circ} \mathrm{C}\end{array}$ & -1.3 & 2.6 & 5.0 & 9.5 & 11.8 & 12.6 & 10.2 & 7.8 \\
\hline $\begin{array}{l}\text { Radiation received, } \\
\mathrm{MJm}^{-2}\end{array}$ & 173.6 & 163 & 258.1 & 287.7 & 336 & 314.1 & 213.2 & 240.6 \\
\hline Relative humidity & 71 & 73 & 63 & 58 & 62 & 61 & 71 & 66 \\
\hline
\end{tabular}




\begin{tabular}{|c|c|c|c|c|c|c|c|c|c|}
\hline $\begin{array}{l}\text { Growing } \\
\text { season }\end{array}$ & $\begin{array}{l}\text { Depth } \\
\mathrm{cm}\end{array}$ & $\mathrm{pH}$ & $\begin{array}{l}\text { SOM } \\
(\mathrm{g} \\
\left.\mathrm{dm}^{-3}\right)\end{array}$ & $\begin{array}{l}\mathrm{Zn} 2^{+} \\
(\mathrm{mg} \\
\left.\mathrm{kg}^{-1}\right)\end{array}$ & $\begin{array}{l}\mathrm{K}^{+} \\
(\mathrm{mg} \\
\left.\mathrm{kg}^{-1}\right)\end{array}$ & $\begin{array}{l}\mathrm{P} \\
(\mathrm{mg} \\
\left.\mathrm{kg}^{-1}\right)\end{array}$ & $\begin{array}{l}\text { total } \\
\mathrm{N} \\
(\%)\end{array}$ & $\mathrm{CaO}$ & $\begin{array}{l}\text { base } \\
\text { saturation } \\
(\%)\end{array}$ \\
\hline \multirow[t]{2}{*}{2018} & $0-15$ & 7.8 & 10.3 & 18 & 212 & 8.29 & 0.06 & 14.4 & 49 \\
\hline & $15-30$ & 7.6 & 6.88 & 13 & 143 & 6.5 & - & 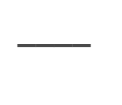 & - \\
\hline \multirow[t]{2}{*}{2019} & $0-15$ & 7.9 & 10.3 & 19 & 220 & 8.9 & 0.06 & 14.5 & 48 \\
\hline & $15-30$ & 7.7 & 6.88 & 15 & 152 & 6 & - & 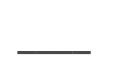 & - \\
\hline
\end{tabular}

TABLE 3 | Effects of various plant densities of faba bean on yield and yield component of faba bean and soil properties in both years.

Similar letter in each column indicate no significant difference at $5 \%$ probability level using LSD multiple range test.

TABLE 4 | Effects of various densities of faba bean and $\mathrm{N}$ fertilizer application on $\mathrm{N}$ content, Crude protein and Dry matter production of forage corn in both years. 


\begin{tabular}{|c|c|c|c|c|c|c|}
\hline Treatment & $\begin{array}{l}\text { N. of } \\
\text { pod (per } \\
\text { plant) }\end{array}$ & $\begin{array}{l}\text { N. of } \\
\text { Grain } \\
\text { (per } \\
\text { plant) }\end{array}$ & $\begin{array}{l}\text { Yield } \\
\text { (ton } \\
\mathrm{ha}^{-1} \text { ) }\end{array}$ & $\begin{array}{l}\text { Dry } \\
\text { biomass } \\
\text { (ton ha }^{-1} \text { ) }\end{array}$ & $\begin{array}{l}\text { infiltration rate } \\
\text { of soil ( } \mathrm{mm} \\
\left.\mathrm{sec}^{-1}\right)\end{array}$ & $\begin{array}{l}\text { moisture } \\
\text { content of } \\
\text { soil (\%) }\end{array}$ \\
\hline \multicolumn{7}{|l|}{$\begin{array}{l}\text { Varied densities } \\
\text { of faba bean }\end{array}$} \\
\hline \multicolumn{7}{|l|}{ Year (2018) } \\
\hline $\begin{array}{l}A_{1}(80 \text { plant per } \\
\left.m^{-2}\right)\end{array}$ & $5.3 \mathrm{c}$ & $11.1 \mathrm{~b}$ & 3.6 a & $5.39 a$ & 110.1 a & $23.3 \mathrm{ab}$ \\
\hline $\begin{array}{l}A_{2}(40 \text { plant per } \\
\left.m^{-2}\right)\end{array}$ & $10.1 \mathrm{~b}$ & $21.1 \mathrm{a}$ & $3.48 \mathrm{a}$ & $4.59 a b$ & $123.8 \mathrm{ab}$ & $24.6 \mathrm{a}$ \\
\hline $\begin{array}{l}\mathrm{A}_{3}(35 \text { plant per } \\
\left.\mathrm{m}^{-2}\right)\end{array}$ & $10.7 \mathrm{~b}$ & $21.6 \mathrm{a}$ & $2.16 \mathrm{~b}$ & $3.67 \mathrm{bc}$ & 139.6 bc & $19.2 \mathrm{bc}$ \\
\hline $\begin{array}{l}A_{4}(25 \text { plant per } \\
\left.m^{-2}\right)\end{array}$ & $14.1 \mathrm{a}$ & $25.8 \mathrm{a}$ & $1.77 \mathrm{~b}$ & $3.54 \mathrm{c}$ & $142.4 \mathrm{bc}$ & $19.4 \mathrm{bc}$ \\
\hline $\begin{array}{l}\mathrm{A}_{5} \text { (Monocropped } \\
\text { maize) }\end{array}$ & - & - & - & - & $152.67 \mathrm{c}$ & $17.7 \mathrm{c}$ \\
\hline F value & $<0.05$ & $<0.00$ & $<0.00$ & $<0.00$ & $<0.05$ & $<0.05$ \\
\hline CV (\%) & 15.1 & 12.1 & 13.6 & 11.1 & 11.2 & 12.9 \\
\hline \multicolumn{7}{|l|}{ Year (2019) } \\
\hline $\begin{array}{l}A_{1}(80 \text { plant per } \\
\left.m^{-2}\right)\end{array}$ & $5.94 \mathrm{c}$ & $11.58 \mathrm{c}$ & $3.9 \mathrm{a}$ & $5.66 \mathrm{a}$ & $113.6 \mathrm{a}$ & 26.9 a \\
\hline $\begin{array}{l}A_{2}(40 \text { plant per } \\
\left.m^{-2}\right)\end{array}$ & $11.1 \mathrm{~b}$ & $22.4 \mathrm{~b}$ & $3.81 \mathrm{a}$ & $4.76 a b$ & $118.4 \mathrm{a}$ & $27.3 \mathrm{a}$ \\
\hline $\begin{array}{l}A_{3}(35 \text { plant per } \\
\left.m^{-2}\right)\end{array}$ & $13.07 \mathrm{~b}$ & $22.97 \mathrm{ab}$ & $2.52 \mathrm{~b}$ & $3.85 b$ & $140.2 \mathrm{~b}$ & $18.9 \mathrm{~b}$ \\
\hline $\begin{array}{l}A_{4}(25 \text { plant per } \\
\left.\mathrm{m}^{-2}\right)\end{array}$ & $17.1 \mathrm{a}$ & $27.2 \mathrm{a}$ & $2.1 \mathrm{~b}$ & $3.83 \mathrm{~b}$ & $140.3 \mathrm{~b}$ & $19.5 \mathrm{~b}$ \\
\hline $\begin{array}{l}\mathrm{A}_{5} \text { (Monocropped } \\
\text { maize) }\end{array}$ & - & - & - & - & $148.6 \mathrm{bc}$ & $18.6 \mathrm{~b}$ \\
\hline F value & $<0.05$ & $<0.01$ & $<0.01$ & $<0.01$ & $<0.05$ & $<0.05$ \\
\hline CV (\%) & 10.1 & 11.1 & 14.6 & 12.3 & 11.4 & 15.8 \\
\hline
\end{tabular}




\begin{tabular}{|c|c|c|c|c|}
\hline Treatment & $\begin{array}{l}\mathrm{N} \\
\text { content } \\
\text { (kg ha- } \\
1 \text { ) }\end{array}$ & $\begin{array}{l}\text { Crude } \\
\text { protein } \\
\left(\mathrm{kg} \mathrm{ha}^{-1}\right)\end{array}$ & $\begin{array}{l}\text { Fresh matter } \\
\text { production (ton } \\
\mathrm{ha}^{-1} \text { ) }\end{array}$ & $\begin{array}{l}\text { Dry matter } \\
\text { production (ton } \\
\mathrm{ha}^{-1} \text { ) }\end{array}$ \\
\hline \multicolumn{5}{|l|}{ Year (2018) } \\
\hline $\begin{array}{l}\left.\text { Faba bean density ( } 40 \text { plant per } \mathrm{m}^{2}\right) \\
+\mathrm{N} \text { fertilizer application }\left(200 \mathrm{~kg} \mathrm{ha}^{-}\right. \\
\left.{ }^{1}\right)\end{array}$ & $\begin{array}{l}310.23 \\
a\end{array}$ & 1938.97 a & $59.97 \mathrm{ab}$ & $15.2 \mathrm{a}$ \\
\hline $\begin{array}{l}\left.\text { Faba bean density ( } 40 \text { plant per } \mathrm{m}^{2}\right) \\
+\mathrm{N} \text { fertilizer application }\left(100 \mathrm{~kg} \mathrm{ha}^{-1}\right)\end{array}$ & $\begin{array}{l}290.83 \\
a b\end{array}$ & $\begin{array}{l}1817.73 \\
a b\end{array}$ & $61.43 a$ & $13.3 \mathrm{ab}$ \\
\hline $\begin{array}{l}\left.\text { Faba bean density ( } 80 \text { plant per } \mathrm{m}^{2}\right) \\
+\mathrm{N} \text { fertilizer application }\left(300 \mathrm{~kg} \mathrm{ha}^{-1}\right)\end{array}$ & $\begin{array}{l}277.3 \\
a b c\end{array}$ & $\begin{array}{l}1733.13 \\
\text { abc }\end{array}$ & $60.6 \mathrm{ab}$ & $13.73 \mathrm{ab}$ \\
\hline $\begin{array}{l}\text { Monocultured corn without of } \mathrm{N} \\
\text { fertilizer application }\end{array}$ & $72.57 \mathrm{~h}$ & $452.63 \mathrm{~h}$ & $42.9 \mathrm{~h}$ & $8.43 \mathrm{~h}$ \\
\hline F value & $<0.00$ & $<0.00$ & $<0.01$ & $<0.00$ \\
\hline CV (\%) & 19.5 & 19.5 & 11.8 & 13.8 \\
\hline \multicolumn{5}{|l|}{ Year (2019) } \\
\hline $\begin{array}{l}\left.\text { Faba bean density ( } 40 \text { plant per } \mathrm{m}^{2}\right) \\
+\mathrm{N} \text { fertilizer application }\left(200 \mathrm{~kg} \mathrm{ha}^{-1}\right)\end{array}$ & $\begin{array}{l}322.23 \\
a\end{array}$ & 2013.94 a & $65.13 \mathrm{ab}$ & $15.77 \mathrm{a}$ \\
\hline $\begin{array}{l}\left.\text { Faba bean density ( } 40 \text { plant per } \mathrm{m}^{2}\right) \\
+\mathrm{N} \text { fertilizer application }\left(100 \mathrm{~kg} \mathrm{ha}^{-1}\right)\end{array}$ & $\begin{array}{l}338.87 \\
a\end{array}$ & $2117.94 a$ & $71.77 \mathrm{a}$ & $14.07 \mathrm{ab}$ \\
\hline $\begin{array}{l}\left.\text { Faba bean density ( } 80 \text { plant per } \mathrm{m}^{2}\right) \\
+\mathrm{N} \text { fertilizer application }\left(300 \mathrm{~kg} \mathrm{ha}^{-1}\right)\end{array}$ & $\begin{array}{l}289.3 \\
a b\end{array}$ & $\begin{array}{l}1808.13 \\
a b\end{array}$ & $63.17 \mathrm{abc}$ & $12.83 \mathrm{abc}$ \\
\hline $\begin{array}{l}\text { Monocultured corn without of } \mathrm{N} \\
\text { fertilizer application }\end{array}$ & $77.9 \mathrm{~h}$ & $480.63 \mathrm{~h}$ & $41.63 \mathrm{~h}$ & $8.77 \mathrm{~h}$ \\
\hline F value & $<0.00$ & $<0.00$ & $<0.00$ & $<0.00$ \\
\hline CV (\%) & 19.7 & 19.7 & 14.1 & 13.8 \\
\hline
\end{tabular}

Similar letter in each column indicate no significant difference at 5\% probability level using LSD multiple range test.

\section{Figures}




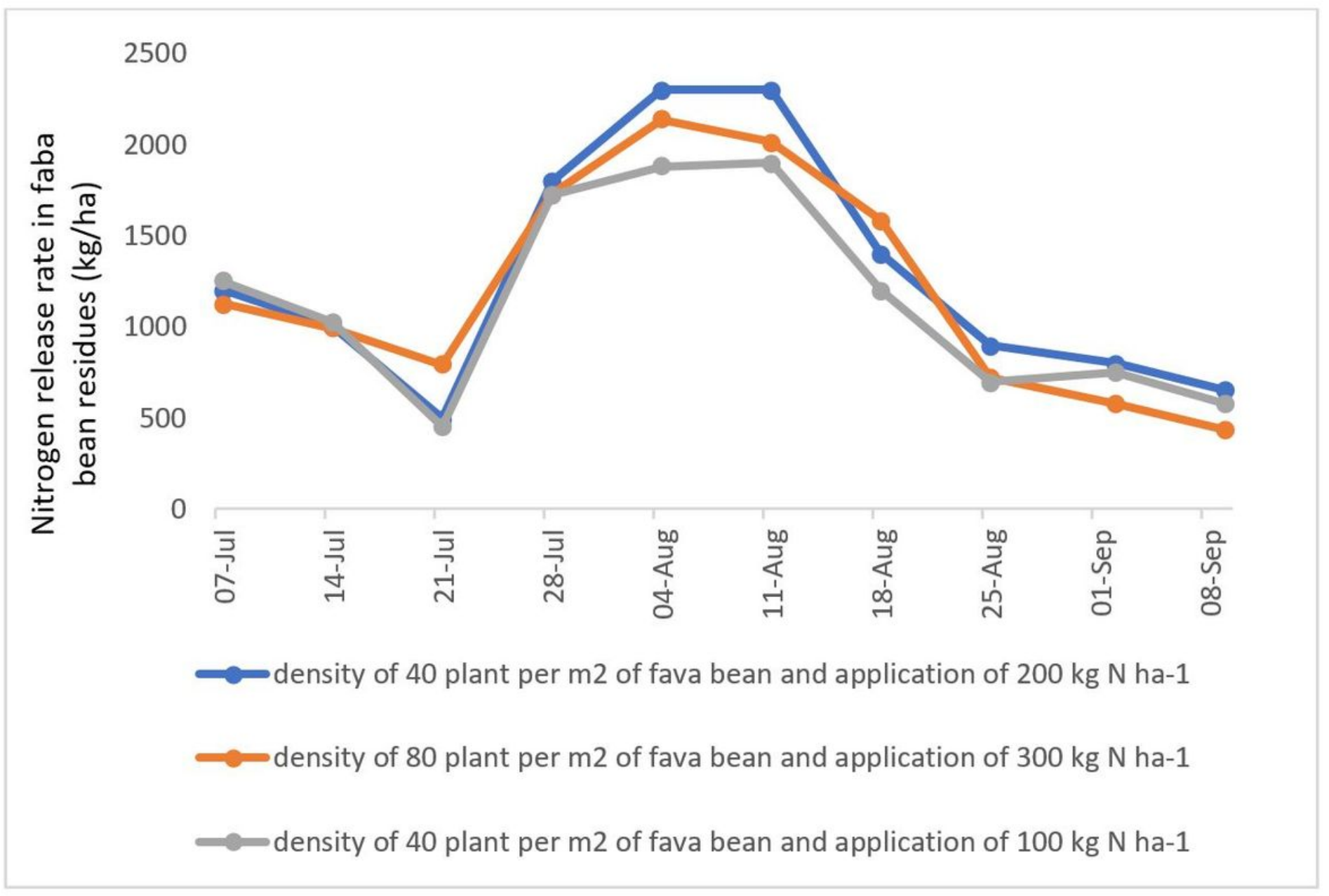

\section{Figure 1}

Nitrogen release trend from decomposing faba bean residues in the first year 


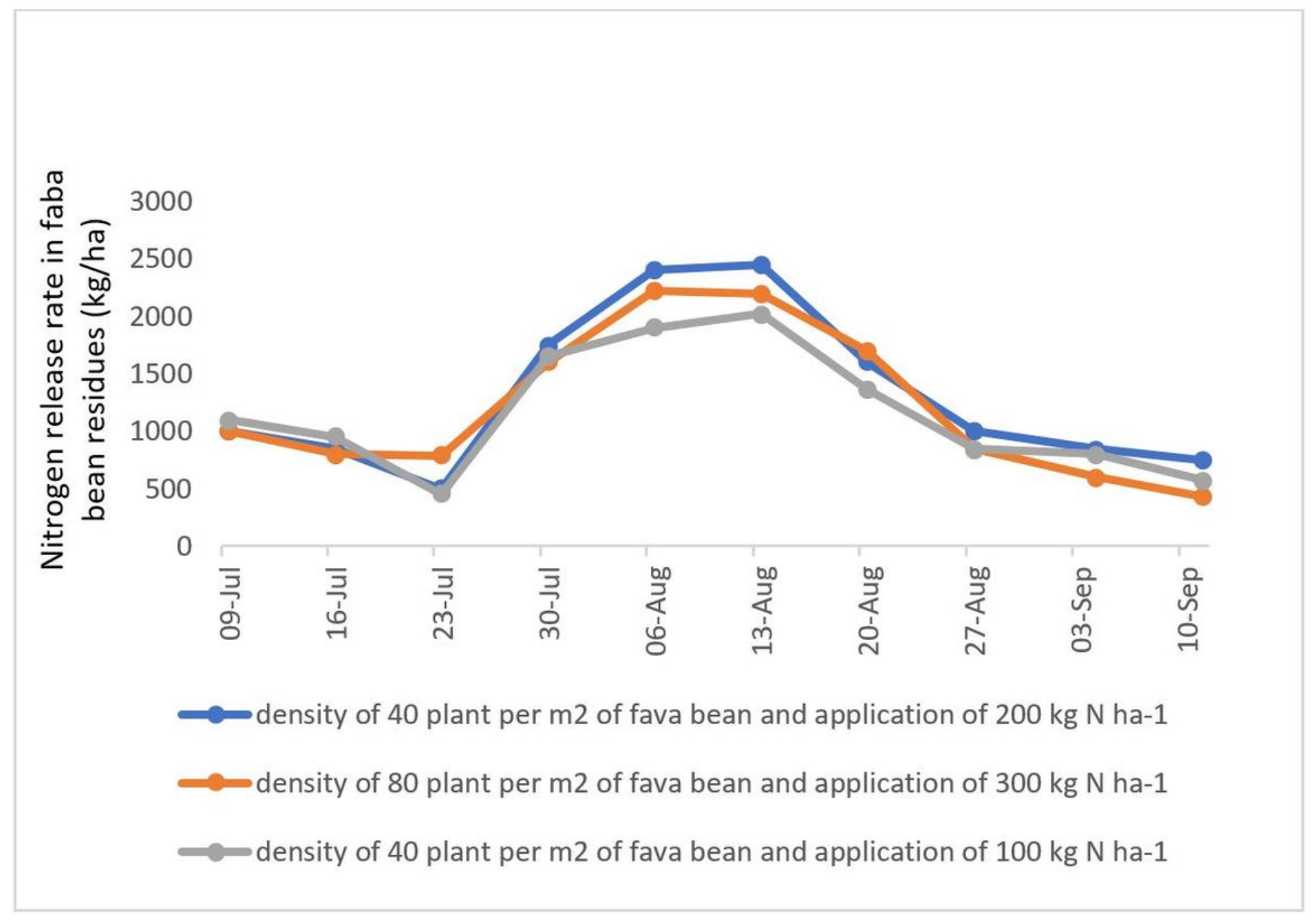

\section{Figure 2}

Nitrogen release trend from decomposing faba bean residues in the second year 